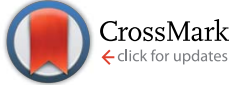

Cite this: RSC Adv., 2017, 7, 6266

\title{
Introduction of a long-chain branching structure by ultraviolet-induced reactive extrusion to improve cell morphology and processing properties of polylactide foam
}

\begin{abstract}
Shaojie Li, ${ }^{a}$ Guangjian He, ${ }^{b}$ Xia Liao, ${ }^{\star a b}$ Chul B. Park, ${ }^{\text {ac }}$ Qi Yang ${ }^{a}$ and Guangxian Li ${ }^{\star a}$
In this paper, long-chain branched polylactide (LCB-PLA) prepared by UV-induced reaction extrusion with trimethylolpropane triacrylate (TMPTA) was foamed by supercritical carbon dioxide $\left(\mathrm{sCCO}_{2}\right)$, and the effect of the long-chain branching structure on the cell morphologies of PLA foams was investigated. The LCBPLA displayed higher complex viscosity, melting point and crystal nucleation potential under $\mathrm{SCCO}_{2}$, and these factors could influence the foaming behavior of PLA which was proved by the different cell morphologies of samples foamed after various saturation times. The advantage of LCB-PLA on foaming was remarkable at high temperature and high pressure. LCB-PLA with more than 0.5\% TMPTA showed nano-cells while the other samples showed micro-cells at $142{ }^{\circ} \mathrm{C}$ under $12 \mathrm{MPa}$, and the samples displayed elliptic cells with horizontal semimajor axis in linear PLA and circular cells or oval cells with vertical semimajor axis in LCB-PLA with increasing temperature. The improved cell morphology with reduced coalescence, no collapse and uniform cell distribution was also shown in LCB-PLA under higher pressure. All these results were due to the increasing matrix strength and higher crystal nucleation potential of LCB-PLA. The findings indicate that LCB-PLA possesses better foaming behavior at high temperature and high pressure. The wide foaming processing window of LCB-PLA would benefit the high temperature and high pressure foaming of PLA such as bead foaming and continuous extrusion foaming, thus broadening its application.
\end{abstract}

Received 7th November 2016 Accepted 10th January 2017

DOI: 10.1039/c6ra26457c

www.rsc.org/advances

\section{Introduction}

PLA has drawn much attention in recent decades due to its biodegradable and biocompatible nature. ${ }^{1-5}$ PLA can be produced from renewable resources, ${ }^{6-8}$ and its degradation components are environmental friendly, which make it a promising material to substitute petroleum-based polymer. Thanks to these properties, PLA possesses numerous applications such as being used as packaging materials, biomedical materials, for containers and so on. ${ }^{1,9-11}$ To reduce the cost and improve the mechanical properties of PLA, foaming technology is usually considered, ${ }^{12}$ and the PLA foams are thought to be a promising material to replace polystyrene (PS) foams. ${ }^{13}$ In

\footnotetext{
${ }^{a}$ College of Polymer Science and Engineering, State Key Laboratory of Polymer Materials Engineering, Sichuan University, Chengdu, Sichuan 610065, China. E-mail: xliao@scu.edu.cn; guangxianli@scu.edu.cn; Tel: +86-28-8540-8361; +86-28-8546-9011

${ }^{b}$ The Key Laboratory of Polymer Processing Engineering of Ministry of Education, National Engineering Research Center of Novel Equipment for Polymer Processing, South China University of Technology, Guangzhou 510640, China

'Microcellular Plastics Manufacturing Laboratory, Department of Mechanical and Industrial Engineering, University of Toronto, 5 King's College Road, Toronto, Ontario, Canada M5S $3 G 8$
}

recent years, many studies have focused on the low temperature foaming of PLA, ${ }^{14-16}$ but the use of melt foaming processes, such as bead foaming and continuous extrusion foaming, is significant especially in industry due to their high efficiency. However, the high temperature employed during melt foaming would be a big challenge for PLA due to its poor melt strength. Thus, the modification of PLA to enhance its melt strength is required.

The introduction of long chain branching structure into polymer is proved to be an efficient way to enhance its matrix strength, ${ }^{17-20}$ which could benefit the $\mathrm{scCO}_{2}$ foaming of polymer. ${ }^{20-22}$ It was found that the long-chain branching structure decreased the degree of coalescence in polymers, and the higher cell density was observed in branched polymers due to its enhanced melt strength. To introduce the branching structure, the most common way is reactive extrusion with peroxide initiator. Mohebbi et al. ${ }^{18}$ prepared LCB-PP by reactive extrusion process in the presence of peroxide, multi-functional monomer and co-agent. It was found that the storage modulus and viscosity increased when PP was branched, and the thermal stability of branched PP was improved. Wang et al. ${ }^{22}$ prepared the long-chain branched PP via an novel extrusion reaction in the presence of $\mathrm{CO}_{2}$ and the sample was foamed at the same time of branching. The combination of grafting and foaming 
enhanced the efficiency of fabrication, and it was proved that the foaming windows were expanded in the presence of $\mathrm{scCO}_{2}$. However, the peroxide initiator used during reactive extrusion would remain in the products, which may lead to the formation of secondary production and impart a disagreeable odor to the resin, thus affected the properties of the polymer. Alternative method to introduce long chain branching structure is highenergy irradiation, which would induce radical reactions of polymers without employing peroxide initiator. Fang et al. ${ }^{9}$ prepared LCB-PLA via an batch processing method: the PLA and trimethylolpropane triacrylate (TMPTA) were first blended, then the sample was subject to gamma rays. Nevertheless, the efficiency of this batch processing method may not meet the requirement of the industry. In our previous study, ${ }^{23}$ LCB-PLA was prepared via in situ ultraviolet (UV)-induced reactive extrusion of molten PLA with TMPTA, without employing a peroxide initiator. Through this technology, chain scission reaction of PLA was promoted to a high-level efficiency. After modification, the melt strength was enhanced and the crystallization rate was improved because of the nucleation effect of long-chain branching structure.

Thanks to its enhanced matrix strength and improved crystallization behavior, LCB-PLA possesses immense potential in the region of foaming at high temperature because of the significant differences in matrix strength and crystal nucleation effect between linear PLA and LCB-PLA foams. In this study, the LCB-PLA prepared by in situ UV-induced reactive extrusion process has been foamed using $\mathrm{scCO}_{2}$ as blowing agent at high temperature, and the effect of the crystallization behavior and rheology property on the cell morphology were discussed. The results indicated that the long-chain branching structure introduced by UV-induce reactive extrusion would benefit the foaming behavior of PLA especially at high temperature and high pressure, thus expanded its foaming processing window and widen the application of PLA.

\section{Experiment}

\section{Materials}

The PLA (4032D) used in this study was purchased from NatureWorks LLC Co. (USA), with density of $1.24 \mathrm{~g} \mathrm{~cm}^{-3}$. The LCB-PLA was produced using UV induced reaction extrusion and TMPTA was used as a trifunctional monomer. The details of the preparation and structure of LCB-PLA was reported in our previous research. ${ }^{23}$ It was found that the degree of branching in LCB-PLA increased with increasing TMPTA content. For samples identification purpose, LCB-PLA with TMPTA content of $0.5 \mathrm{wt} \%, 1 \mathrm{wt} \%, 1.5 \mathrm{wt} \%$ and $2 \mathrm{wt} \%$ will be referred to as PLA05, PLA10, PLA15 and PLA20.

\section{Preparation of LCB-PLA foams by supercritical $\mathrm{CO}_{2}$}

The LCB-PLA foams produced by batch foaming process using $\mathrm{CO}_{2}$ as foaming agents was described by Goel and Beckman earlier. ${ }^{24}$ The samples with thickness of $0.4 \mathrm{~mm}$ were prepared by compression molding under vacuum at $180{ }^{\circ} \mathrm{C}$ and then cut into the dimensions of $10 \times 10 \mathrm{~mm}^{2}$ for foaming. The sample was then placed into a high-pressure vessel which was preheated to the experimental temperature. After flushed by low pressure $\mathrm{CO}_{2}$ for $5 \mathrm{~min}$, the high-pressure vessel was pressurized to experimental pressure. Following the saturation, the samples underwent a rapid quench of pressure (about $3 \mathrm{~s}$ ) for cell nucleation and growth. Subsequently, the high-pressure vessel was cooled down to room temperature and the sample was taken out from the vessel.

\section{Characterization}

A scanning electronic microscope (SEM) was used to characterize the cell morphologies of LCB-PLA foams on a Jeol SEM (model JSM 5900LV, Tokyo, Japan). The foamed samples were fractured in liquid nitrogen and then sputter coated with gold. The cell density and average cell diameter of samples were estimated from SEM images using image analysis software (Image Pro Plus). The cell density of foams was determined by eqn (1) as follow:

$$
N_{\mathrm{f}}=\left(n M^{2} / A\right)^{3 / 2}
$$

where $N_{\mathrm{f}}$ (cells per $\mathrm{cm}^{3}$ ) is cell density of the sample, $n$ is the number of cells in specific region, $M$ is the magnification factor and $A$ is the area of specific region.

Differential scanning calorimetry (DSC) experiment was performed on Q20 (TA Instrument, American). The foamed samples weighted about $5 \mathrm{mg}$ were heated in a nitrogen atmosphere from $20{ }^{\circ} \mathrm{C}$ to $200{ }^{\circ} \mathrm{C}$ at a heating rate of $5{ }^{\circ} \mathrm{C} \mathrm{min}{ }^{-1}$.

The thermal behavior (non-isothermal crystallization and isothermal crystallization) of LCB-PLA under $\mathrm{CO}_{2}$ was tested by high-pressure DSC (Sensys Evo, Setaram, France). For nonisothermal crystallization, after the sample was placed into the cell, the cell was pressurized to experimental pressure. To eliminate the thermal and stress history, the sample was first heated to $180{ }^{\circ} \mathrm{C}$ at a heating rate of $10{ }^{\circ} \mathrm{C} \mathrm{min}{ }^{-1}$ and kept at $180^{\circ} \mathrm{C}$ for $5 \mathrm{~min}$. Then, it was cooled down to $20^{\circ} \mathrm{C}$ at a rate of $2{ }^{\circ} \mathrm{C} \mathrm{min}{ }^{-1}$. Subsequently, it was heated to $80{ }^{\circ} \mathrm{C}$ and kept for 10 min to complete the phase transition of $\mathrm{CO}_{2}$. Finally, it was heated to $200{ }^{\circ} \mathrm{C}$ at a heating rate of $5{ }^{\circ} \mathrm{C} \mathrm{min}^{-1}$. For isothermal crystallization, the samples were first heated to $180^{\circ} \mathrm{C}$ and kept for $5 \mathrm{~min}$. Then, it is cooled down to experiment temperature at a cooling rate of $20^{\circ} \mathrm{C} \mathrm{min}^{-1}$. After 4 h's crystallization, it was cooled to $40{ }^{\circ} \mathrm{C}$ at a rate of $20{ }^{\circ} \mathrm{C} \mathrm{min}{ }^{-1}$, and the $\mathrm{CO}_{2}$ was released slowly (for about $30 \mathrm{~min}$ ) after cooling. Finally, it was heated to $200{ }^{\circ} \mathrm{C}$ at a heating rate of $5{ }^{\circ} \mathrm{C} \mathrm{min}{ }^{-1}$. The crystallinity was calculated according to eqn (2) as follow:

$$
\chi=\left(\Delta H_{\mathrm{m}}-\Delta H_{\mathrm{cc}}\right) \times 100 \% / 93.6
$$

where $\Delta H_{\mathrm{m}}$ is the melting enthalpy, $\Delta H_{\mathrm{cc}}$ the cold crystallization enthalpy, and 93.6 the melting enthalpy in $\mathrm{J} \mathrm{g}^{-1}$ of $100 \%$ crystalline PLA. ${ }^{25}$

High-pressure rheometer (MCR 102, Anton Paar, Austria) was used to study the rheology property of LCB-PLA under $\mathrm{CO}_{2}$. The linear viscoelastic (LVE) region of samples was firstly obtained using amplitude sweep with the frequency of $1 \mathrm{~Hz}$. Then the time sweep with the frequency of $1 \mathrm{~Hz}$ and strain of $1 \%$ (in 
the range of the LVE region) was performed at $180{ }^{\circ} \mathrm{C}$ under $12 \mathrm{MPa} \mathrm{CO}_{2}$.

\section{Results and discussion}

\section{Rheology and crystallization behavior of LCB-PLA under $\mathrm{CO}_{2}$}

The viscosity of PLA could be increased by the long-chain branching structure, thus increasing its matrix strength, which would influence its foaming behavior. Although the rheology behavior of LCB-PLA under high-pressure $\mathrm{CO}_{2}$ is vital for the foaming, there are limited studies on this region. The rheology property of LCB-PLA versus the $\mathrm{CO}_{2}$ saturation time was shown in Fig. 1. It was found that the complex viscosity and storage modulus of all the samples decreased dramatically in the first $2 \mathrm{~h}$ with the $\mathrm{CO}_{2}$ saturation due to the plasticization effect of $\mathrm{CO}_{2} \cdot{ }^{24}$ Then a platform appeared after $2 \mathrm{~h}$ 's saturation because of the saturation equilibrium. Combine the results we got and our previous studies, ${ }^{\mathbf{1 , 2 6}} 4 \mathrm{~h}$ was long enough for the saturation of $\mathrm{CO}_{2}$ into PLA, thus it was selected as saturation time during the study of effect of temperature and pressure on cell morphology of LCB-PLA. It was also found that the complex viscosity and storage modulus of samples increased with increasing TMPTA content, which was consistent with the our previous study using regular rheometer. ${ }^{23}$ It meant that the existence of TMPTA could enhance the matrix strength of PLA under $\mathrm{CO}_{2}$.

Fig. 2 shown the DSC curves of samples after foaming, and the data obtained from samples annealed under air was also shown for comparison. It was found that the foaming temperature and pressure affected the $T_{\mathrm{m}}$ of samples. When annealed under air, the $T_{\mathrm{m}}$ increased with foaming temperature, which was due to the increased molecular mobility and the easier molecular retraction that formed closely packed crystal structure. ${ }^{27}$ However, when foamed under $12 \mathrm{MPa} \mathrm{CO}_{2}$, the $T_{\mathrm{m}}$ increased when foaming temperature increased from $130{ }^{\circ} \mathrm{C}$ to $140{ }^{\circ} \mathrm{C}$, and then decreased with further increasing temperature. When foamed under $20 \mathrm{MPa}$, the $T_{\mathrm{m}}$ decreased with increasing temperature. The different trend of $T_{\mathrm{m}}$ meant the different state of samples under different foaming conditions.

A small melting peak was shown at a relatively low temperature for most of samples. Nofar et $a .^{28}$ attributed the low melting temperature to the crystals that formed during cooling and the high melting temperature to the crystals remaining during annealing. In our cases, the low melting temperature was mainly caused by the crystals formed during foaming and cooling which performed imperfect. When formed at $140{ }^{\circ} \mathrm{C}$ under $20 \mathrm{MPa}$, the area of the low temperature melting peak was nearly same as that of the high melting temperature peak, and only single peak at low temperature was observed when foamed at $150{ }^{\circ} \mathrm{C}$ under $12 \mathrm{MPa}$ and $20 \mathrm{MPa}$. It meant that when foamed at high temperature and high pressure, most of samples or the all sample was in melt state, thus only imperfect crystals formed during foaming and cooling existed in these samples. This theory could be used to explain the higher $T_{\mathrm{m}}$ of samples foamed at relatively low temperature and pressure and lower $T_{\mathrm{m}}$ of samples foamed at relatively high temperature and pressure. More evidence was shown in Fig. 3 and 4 to prove the theory.

As shown in Fig. 3(a), the $T_{\mathrm{m}}$ of samples decreased to lower than $150{ }^{\circ} \mathrm{C}$ when treated by $12 \mathrm{MPa} \mathrm{CO}_{2}$, and the $T_{\mathrm{m}}$ of LCBPLA increased with the increasing TMPTA content as shown in Fig. 3(b). Thus, when foamed at $150{ }^{\circ} \mathrm{C}$ under $12 \mathrm{MPa}$ and $20 \mathrm{MPa}$, the samples were all in melt state. Fig. 4(a) showed secondary heating curves of samples after isothermal crystallization at $150{ }^{\circ} \mathrm{C}$ under $12 \mathrm{MPa}$ for $4 \mathrm{~h}$, and Fig. 4(b) displayed the crystallinity of samples calculated from (a). The $\mathrm{CO}_{2}$ was released slowly before heating to simulate the foaming process. From Fig. 4, it was observe that the cold crystallization point of LCB-PLA was much lower than that of linear PLA, and the crystallinity increased from $10.71 \%$ to $43.36 \%$ with increasing TMPTA content. It indicated that that the LCB-PLA possess higher nucleation potential than linear PLA, and the melting peak in Fig. 2 were because of the crystals formed during foaming and melting crystallization ${ }^{28,29}$ which performed imperfect. Huang et al. ${ }^{30}$ studied the crystallization behavior of PLA using high-pressure DSC, and the relationship between pressure and melting point were summarized as an equation: $\Delta T_{\mathrm{m}}=-0.6-2.1 P_{\mathrm{CO}_{2}}$. Combination with our results obtained from DSC, it was found that the melting point of PLA under $20 \mathrm{MPa}$ was near $130{ }^{\circ} \mathrm{C}$, while that of samples with TMPTA should be higher than $130^{\circ} \mathrm{C}$ from Fig. 3(b). This result proved that a portion of the original crystals started to melt, and then the melts crystallized during foaming and cooling process when foamed at $130{ }^{\circ} \mathrm{C}$ under $20 \mathrm{MPa}$. A higher temperature at $140{ }^{\circ} \mathrm{C}$ would provide more melts for the melting process, thus a bigger area of low temperature was seen. When foamed at $150{ }^{\circ} \mathrm{C}$,
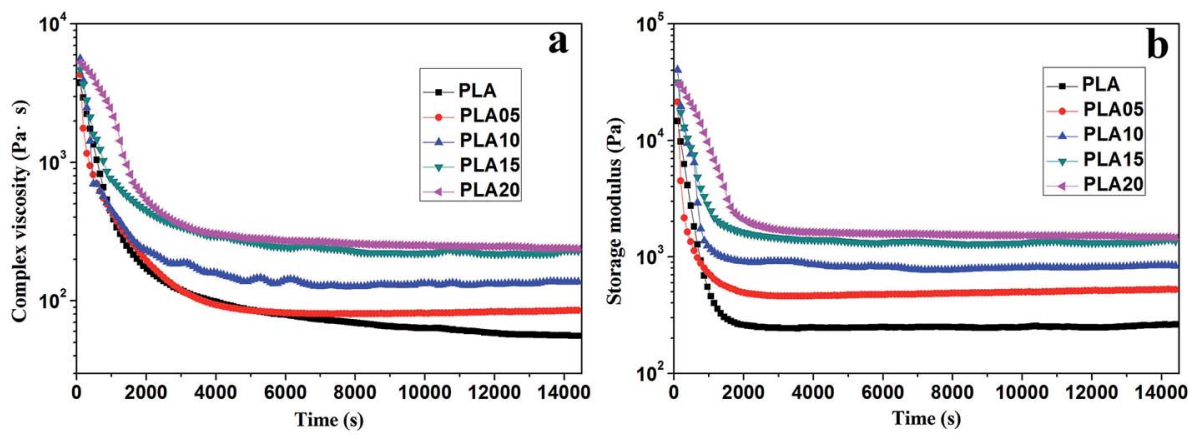

Fig. 1 (a) Complex viscosity and (b) storage modulus of linear PLA and LCB-PLA under $12 \mathrm{MPa} \mathrm{CO}_{2}$ versus time. 
O MPa

$130{ }^{\circ} \mathrm{C}$

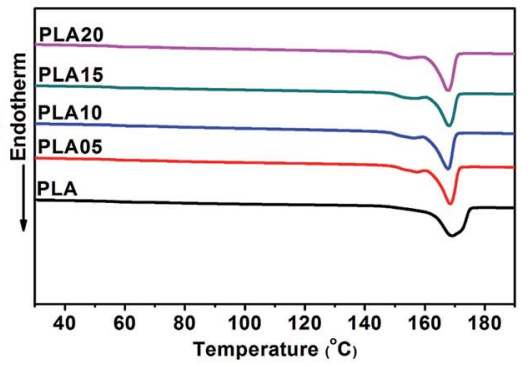

$140{ }^{\circ} \mathrm{C}$
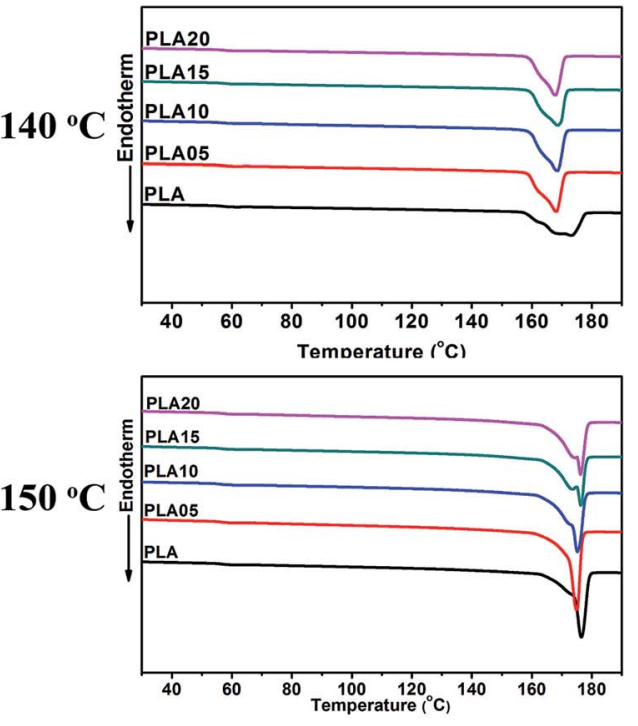

$12 \mathrm{MPa}$
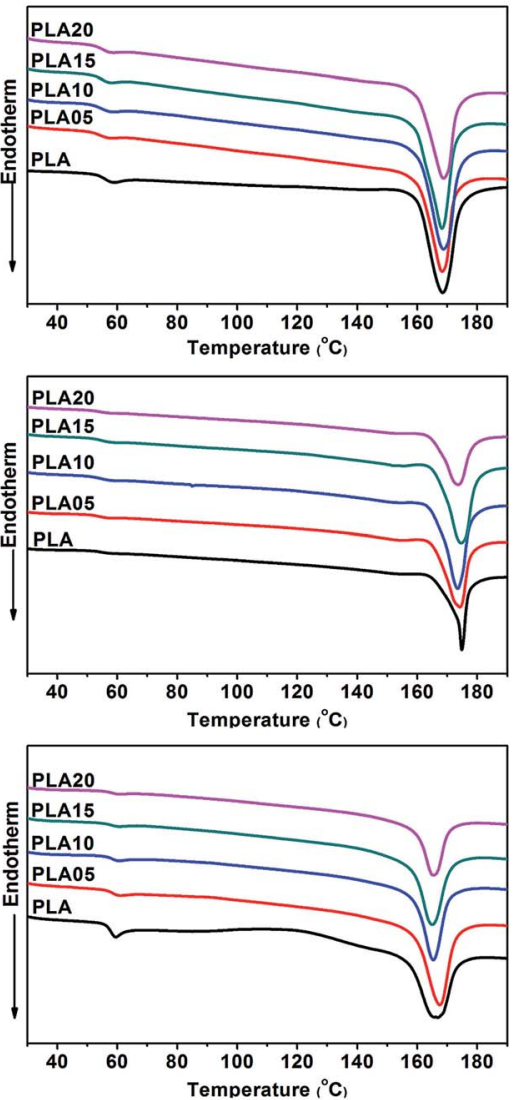

$20 \mathrm{MPa}$
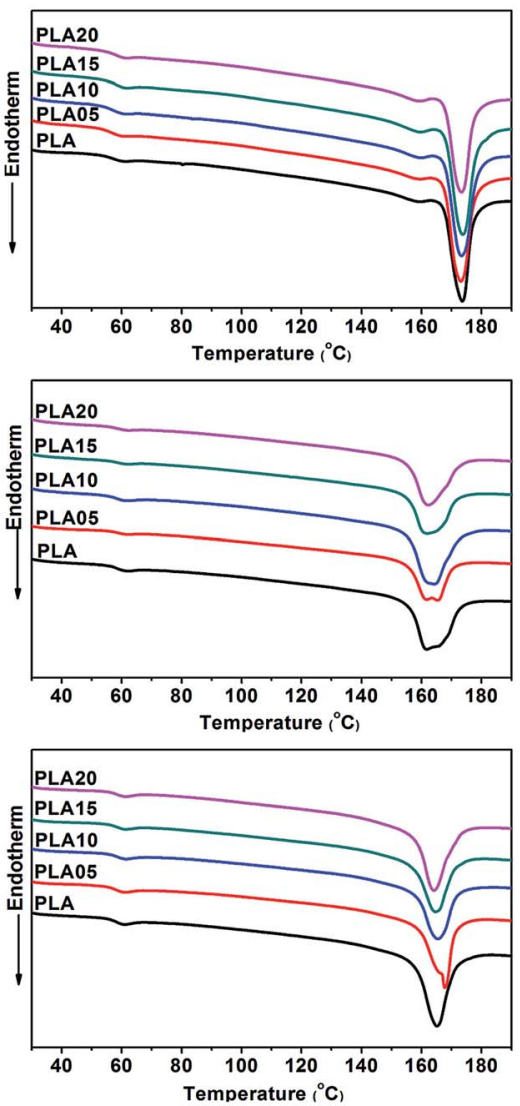

Fig. 2 DSC curves of samples foamed under different conditions.
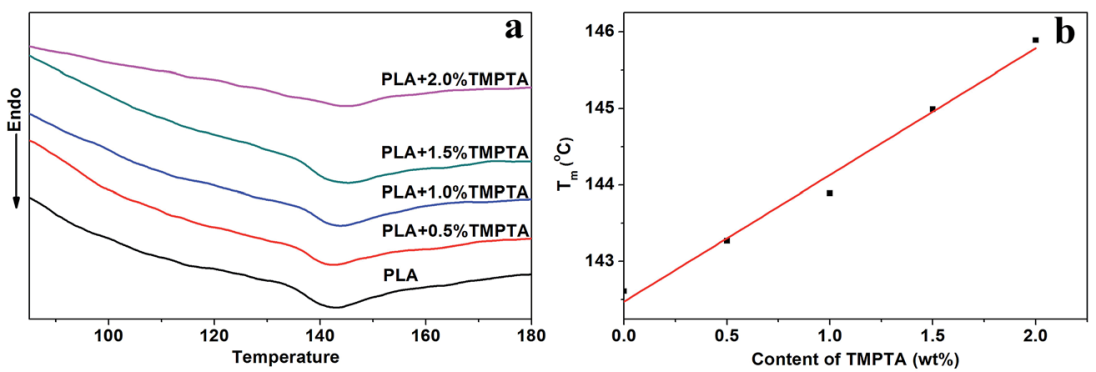

Fig. 3 (a) DSC curves of linear PLA and LCB-PLA under $12 \mathrm{MPa} \mathrm{CO}_{2}$ and (b) $T_{\mathrm{m}}$ of linear PLA and LCB-PLA under $12 \mathrm{MPa} C \mathrm{O}_{2}$

nearly all the samples were melted and the imperfect crystals with lower melting temperature were shown. The crystals formed in the samples during annealing, foaming and cooling may affect the cell morphologies of LCB-PLA foams.

\section{Effect of time on foaming behavior of LCB-PLA}

It is known that it takes time for the adsorption of $\mathrm{CO}_{2}$ into polymer. Thus, the saturation time would influence the foaming behavior of polymer because the saturation time would decide the content of $\mathrm{CO}_{2}$ in polymer. ${ }^{31,32}$ For crystalline polymer like PLA, except the effect of $\mathrm{CO}_{2}$ content in polymer, the different crystallization behavior at different saturation time would also affect its foaming behavior. Fig. 5 displayed the SEM photos of LCB-PLA foamed time at $150{ }^{\circ} \mathrm{C}$ under $8 \mathrm{MPa} \mathrm{CO}_{2}$ during different saturation. It was found that no matter what the saturation time was, the linear PLA possessed the biggest cell diameter with the smallest cell density, which indicated that the long-chain branching structure would increase the matrix strength thus benefit the foaming behavior of PLA. For LCB-PLA foams, different tendency was shown on LCB-PLA with different TMPTA content. When foamed after 0.5 and 1 h's saturation, the PLA05 and PLA10 shown nano-cells with uniform cell distribution, while the PLA15 and PLA20 shown 

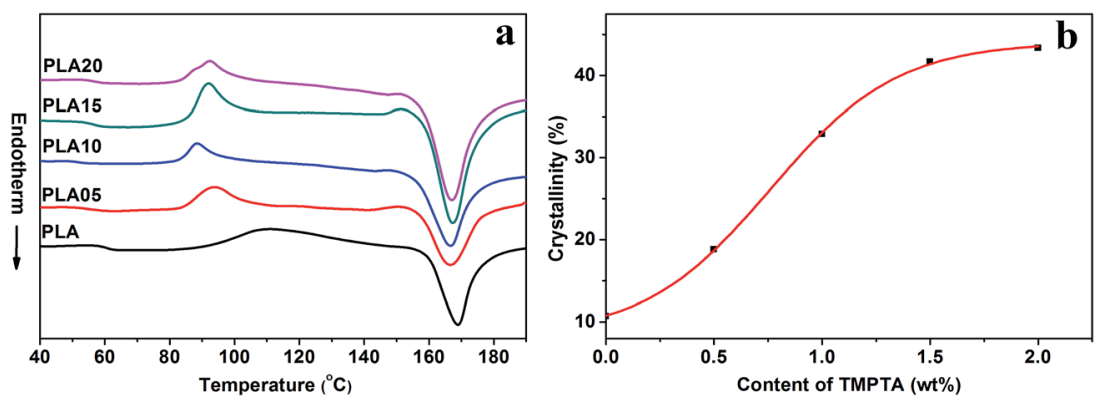

Fig. 4 (a) Secondary heating curves of linear PLA and LCB-PLA experienced isothermal crystallization at $150{ }^{\circ} \mathrm{C}$ under $12 \mathrm{MPa} \mathrm{CO}$ for $4 \mathrm{~h}$ and (b) crystallinity calculated from (a)

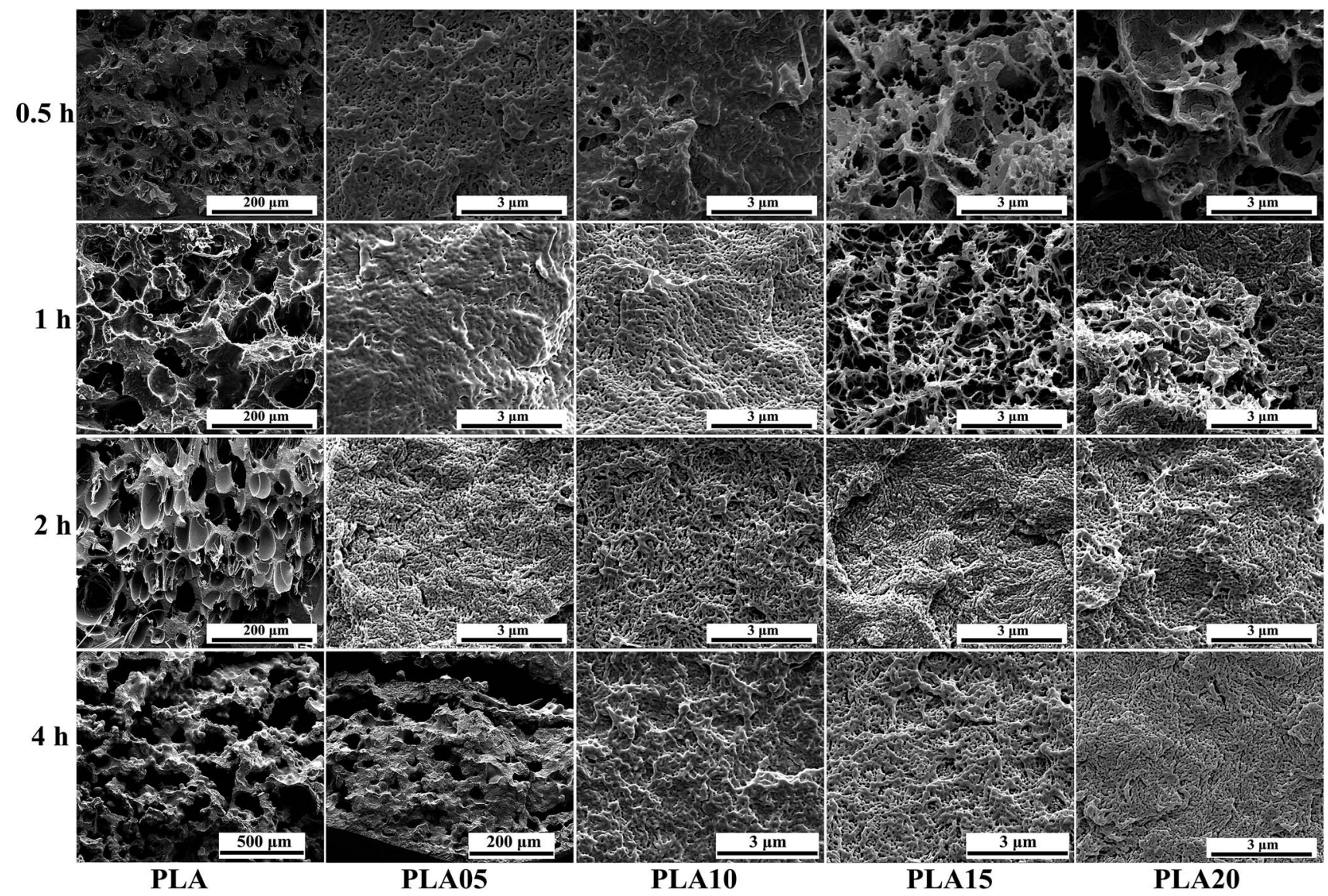

Fig. 5 SEM photos of linear PLA and LCB-PLA foamed at $150{ }^{\circ} \mathrm{C}$ under $8 \mathrm{MPa} \mathrm{CO}$ pressure with different saturation time.

micro-cells with nonuniform cell distribution. With the increasing saturation time to $4 \mathrm{~h}$, the micro-cells with small cell density was shown in PLA05 while the PLA10, PLA15 and PLA20 shown nano-cells. If only the matrix strength was taken into consideration, this phenomenon was so strange. Thus, the effect of crystallization on the cell morphology was nonnegligible. When foaming after a short saturation time such as $0.5 \mathrm{~h}$, the poor molecular chain mobility of LCB-PLA with higher TMPTA content impeded its crystallization, thus the imperfect crystals in these samples were too small to restrict the growth of cells. The cell diameter of PLA15 and PLA20 decreased with the increasing saturation time, which was due to the more perfect crystals was formed after longer time. The micro-cells of PLA05 foamed after 4 h's saturation was caused by its weak matrix strength after a long time $\mathrm{CO}_{2}$ treatment. These results indicated that both the matrix strength and the crystallization behavior of LCB-PLA could affect its foaming behavior. ${ }^{33-35}$

\section{Effect of temperature on foaming behavior of LCB-PLA}

Temperature is crucial to the cell morphology of polymer. When foaming at low temperature, with increasing temperature, the cell size of the amorphous polymer usually increased while the 
$130{ }^{\circ} \mathrm{C}$
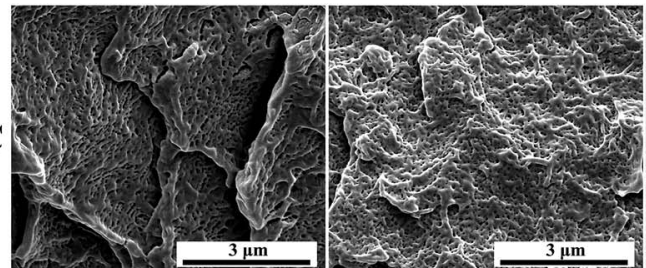

$140{ }^{\circ} \mathrm{C}$

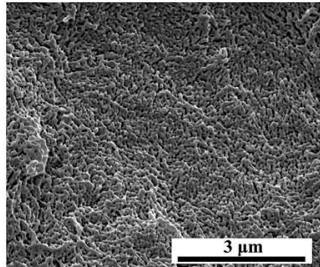

PLA

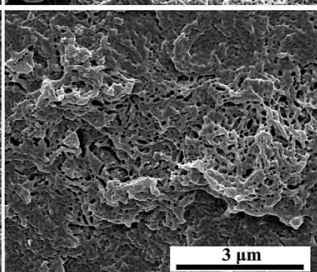

PLA05

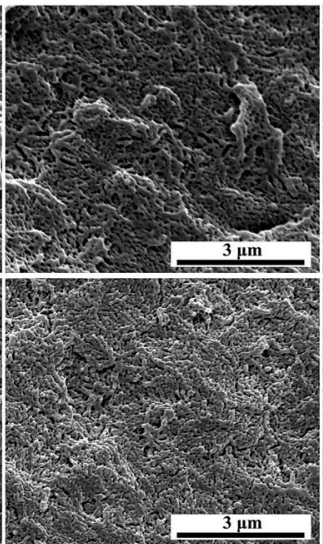

PLA10

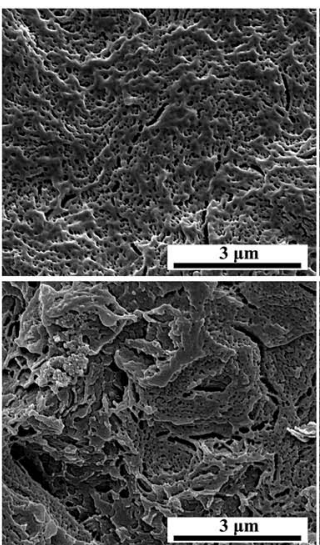

PLA15

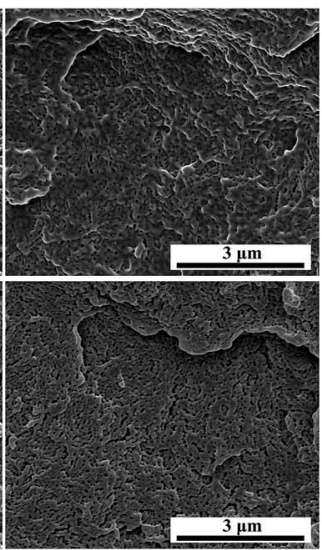

PLA20

Fig. 6 SEM photos of linear PLA and LCB-PLA foamed under $12 \mathrm{MPa}$ at different temperature from $130{ }^{\circ} \mathrm{C}$ to $140{ }^{\circ} \mathrm{C}$

cell density decreased due to the decreasing matrix strength. However, as shown in Fig. 6, there were no significant differences on cell morphology between samples foamed at $130{ }^{\circ} \mathrm{C}$ and $140{ }^{\circ} \mathrm{C}$ under $12 \mathrm{MPa}$ due to the strong matrix strength and crystallization. With the further increasing temperature to $142{ }^{\circ} \mathrm{C}$, micro-sized cells were found in PLA and PLA5 while the nano-sized cells existed in other samples, and the nano-sized cells disappeared when temperature reached $145{ }^{\circ} \mathrm{C}$ which was shown in Fig. 7.

The remarkable phenomenon at $142{ }^{\circ} \mathrm{C}$ could be explained by three reasons: on the one hand, as shown in Fig. 1 , the complex viscosity of samples increased with increasing content of TMPTA, which meant that the addition of TMPTA could strengthen the matrix strength of PLA. The stronger matrix strength restricted the growth and coalescences of cells, thus the nano-sized cells appeared when the content of TMPTA was more than $0.5 \mathrm{wt} \%$. On the other hand, as shown in Fig. 4, the increasing TMPTA content would increase the $T_{\mathrm{m}}$ of PLA. For linear PLA, the melting point was about $142{ }^{\circ} \mathrm{C}$, and that value increased to near $146{ }^{\circ} \mathrm{C}$ for PLA20 under $12 \mathrm{MPa} \mathrm{CO}_{2}$. It meant that the linear PLA and PLA05 may experience the phasetransition during saturation process, which dramatically decreased the viscosity of the samples. Thus the cell morphology changed from nano-cell to micro-cell with the addition of TMPTA at this temperature.

In addition, crystallization is also playing a key role on the cell morphology. ${ }^{26,36}$ When foaming at lower temperature $\left(130{ }^{\circ} \mathrm{C}\right.$ and $\left.140{ }^{\circ} \mathrm{C}\right)$, the cell growth was limited by the more perfect crystals formed during saturation, and the nano-cells thus formed when crystals were connected. As known, the

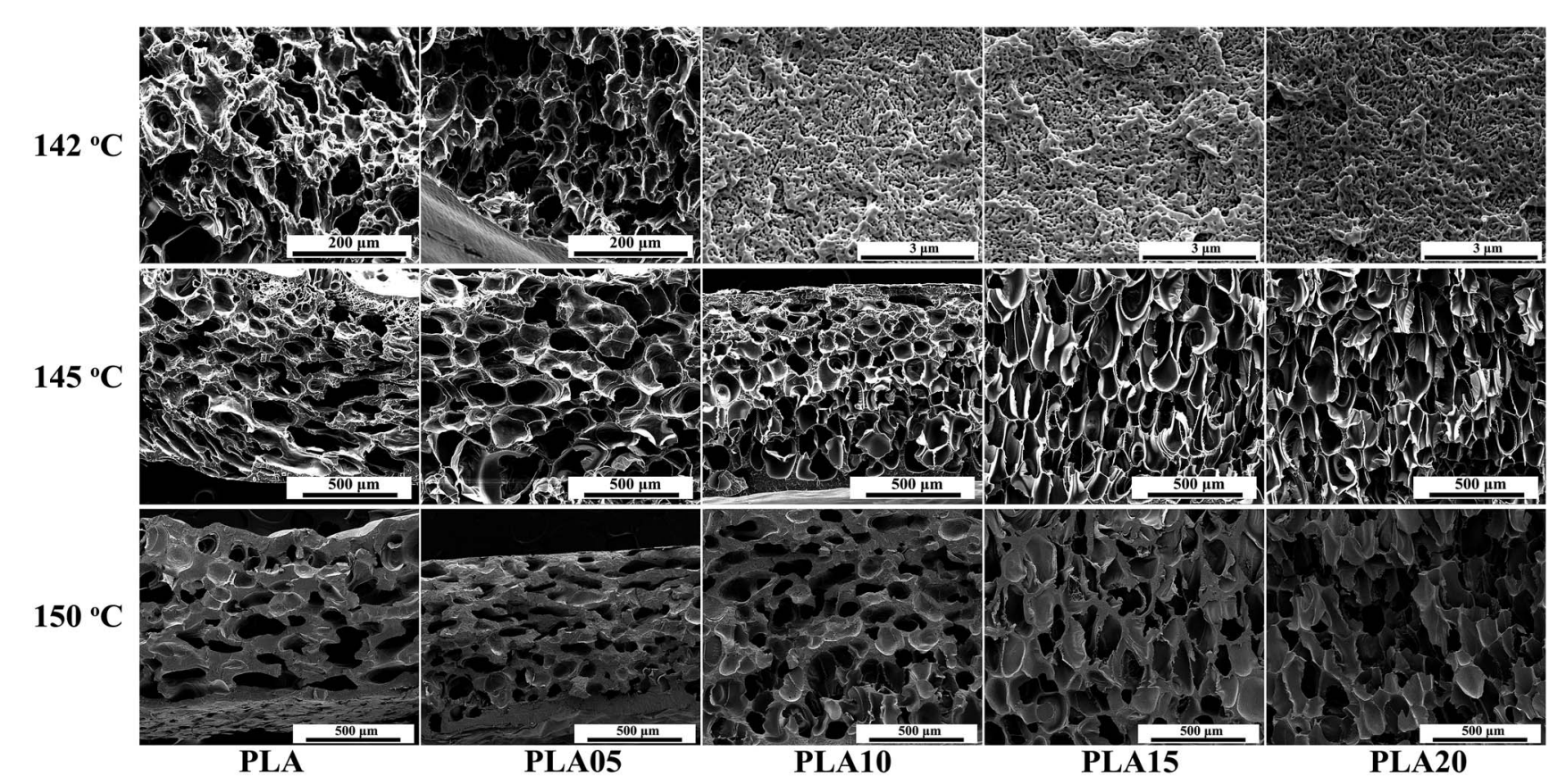

Fig. 7 SEM photos of linear PLA and LCB-PLA foamed under $12 \mathrm{MPa}$ at different temperature from $140{ }^{\circ} \mathrm{C}$ to $150{ }^{\circ} \mathrm{C}$. 

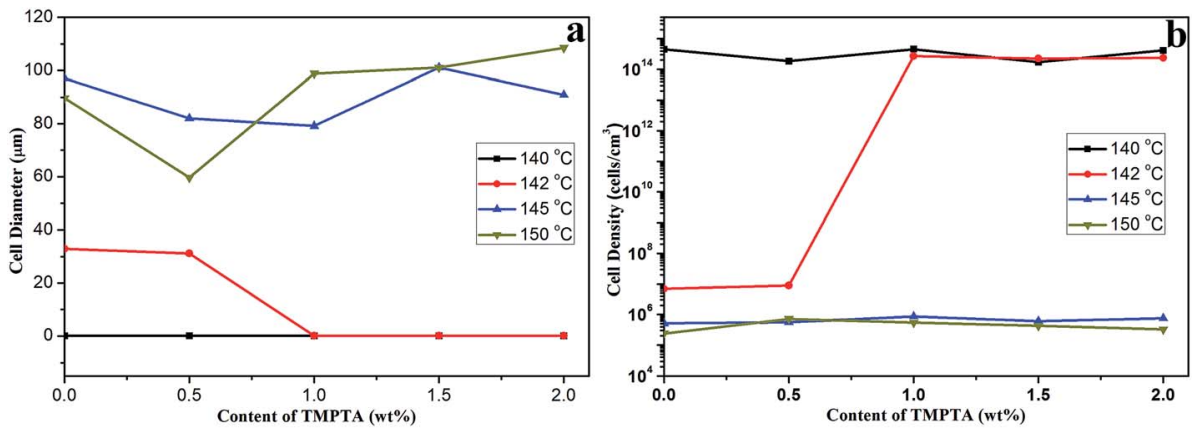

Fig. 8 (a) Average cell diameter and (b) cell density of linear PLA and LCB-PLA with different TMPTA content foamed at different temperature under $12 \mathrm{MPa} \mathrm{CO}_{2}$

higher temperature is benefit to the crystal growth while the lower temperature is benefit to the crystal nucleation. When foaming temperature increased to $142{ }^{\circ} \mathrm{C}$, there were less crystals and some of crystals were formed during cooling and foaming which performed imperfect. Thus the micro-cells appeared in PLA and PLA05. However, the higher crystal nucleation potential of the branching structure ${ }^{37,38}$ made the samples with higher TMPTA content possess crystals just like the samples foamed at lower temperature, and the crystals' percolation caused the nano-cells.

Although all the samples shown micro-cells when foamed at $145{ }^{\circ} \mathrm{C}$ and $150{ }^{\circ} \mathrm{C}$, the cell morphology still showed differences between samples with different TMPTA content. For linear PLA, the elliptic cells with horizontal semimajor axis appeared with thick walls, and with the increasing TMPTA content, the shape of cells became circular or oval cells with vertical semimajor axis and the thickness of walls became thinner. When the content of TMPTA reached $1.5 \mathrm{wt} \%$, the cells even coalesced. The elliptic cells with horizontal semimajor axis of linear PLA possibly caused by the poor melt strength of PLA at high temperature. It was difficult for the cell walls to withstand the internal pressure of cells, thus the cell growth was limited and the cells collapsed and coalesced after foaming. The addition of TMPTA increased the melt strength, thus the stronger cell walls could partly prevent the collapse and coalescence, and the cell diameter became smaller. The further increasing TMPTA content brought about the stronger matrix which would support the cell growth, so the cells became bigger and the cell wall became thinner. However, with the increasing viscosity, the larger cell diameter made it possible for cells to contact with each other, and the coalescence appeared because the matrix was not strong enough to completely prevent the coalescence of cells. Fig. 8 showed the average cell diameter and cell density of samples foamed at different temperature under $12 \mathrm{MPa}$. It was observed that minimum cell diameter at $145^{\circ} \mathrm{C}$ was obtained in PLA10 while that at $150{ }^{\circ} \mathrm{C}$ was obtained in PLA05, which consisted with the analysis.

$\mathrm{Najaf}^{39}$ et al. prepared linear PLA foams, and it was observed that the collapse and coalescence of cells was serious at high temperature just as our results, and, Ren ${ }^{16}$ et al. found that even when chain extender was added, the PLA foams possessed a cell diameter more than $200 \mu \mathrm{m}$ and cell density less than $2 \times 10^{5}$ cell per $\mathrm{cm}^{3}$ at $120^{\circ} \mathrm{C}$. In our cases, the introduction of longchain branching structure could offset the plasticization of $\mathrm{CO}_{2}$ to a certain extent, thus the cell diameter decreased (no more than $100 \mu \mathrm{m}$ ) and cell density increased (more than $2 \times$ $10^{5}$ cell per $\mathrm{cm}^{3}$ ) even at $150{ }^{\circ} \mathrm{C}$. However, the increasing viscosity caused by the TMPTA still couldn't prevent the coalescence at high temperature. The crystallization behavior of samples also affects the cell morphology. The nucleation potential of long-chain branching structure contributed to the formation of nano-cells. The addition of TMPTA widen the processing window of PLA, makes it possible for PLA to be foamed at high temperature.

\section{Effect of pressure on foaming behavior of LCB-PLA}

Pressure is another important processing parameter which influences the cell morphology. On the one hand, higher pressure would enhance the plasticization effect of $\mathrm{CO}_{2}$, thus decrease the matrix strength of polymer, causing larger cell size. On the other hand, higher pressure would decrease the nucleation energy barrier, thus increasing the cell density. Also, the pressure would influence the crystallization of semi-crystalline polymer such as PLA, which would further affect its cell morphology. Fig. 9 showed the SEM photos of LCB-PLA foamed at $130{ }^{\circ} \mathrm{C}$ under different pressure. As shown in Fig. 9, when foamed under $8 \mathrm{MPa} \mathrm{CO}_{2}$, the cell morphology of all samples

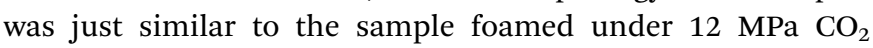
(Fig. 6). However, when foamed under $16 \mathrm{MPa}$, the differences between linear PLA and LCB-PLA became so obvious. The micro-cells formed in linear PLA while only some needle-like cells began to appear in LCB-PLA. The further increasing pressure to $20 \mathrm{MPa}$ made the cell size of linear PLA smaller (nanoscale) while that of LCB-PLA became larger. All these results indicated the complicated effect of $\mathrm{CO}_{2}$ pressure and long-chain branching structure on the foaming behavior of PLA.

When foamed under a low pressure (lower than $12 \mathrm{MPa}$ ), the high strength of the polymer matrix limited the growth of cells, thus the cells with small size were formed. The increasing pressure means more $\mathrm{CO}_{2}$ content, and the strength of the polymer matrix decreased by the enhancing plasticization effect of $\mathrm{CO}_{2}$, so the micro-cell in linear PLA and the needle-like cells in LCB-PLA appeared under $16 \mathrm{MPa}$. A higher pressure at 

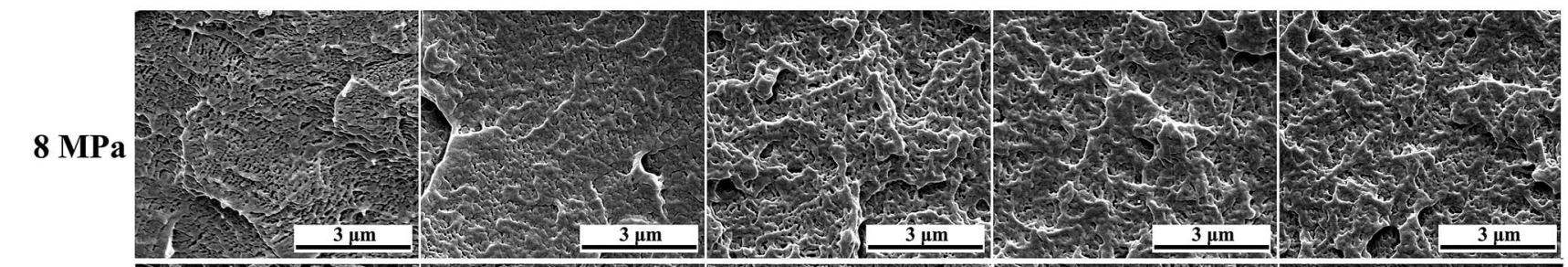

\section{$16 \mathrm{MPa}$}
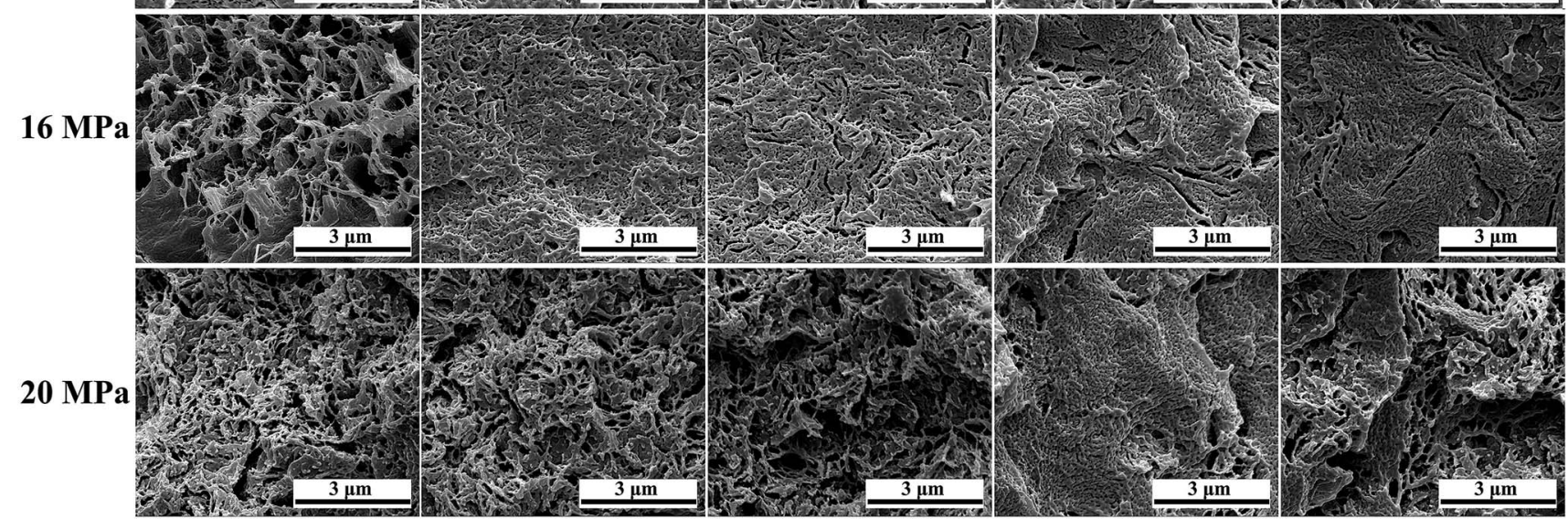

PLA

PLA05

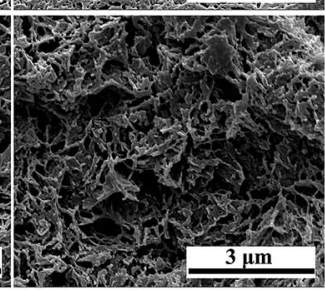

PLA10

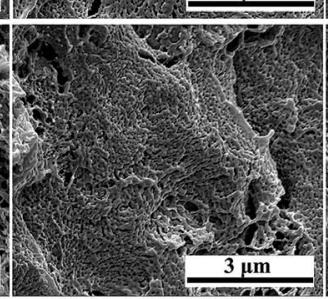

PLA15

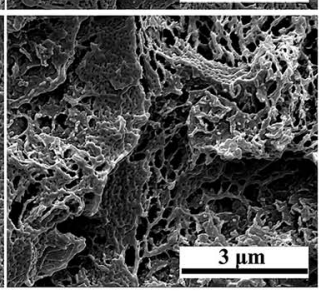

PLA20

Fig. 9 SEM photos of linear PLA and LCB-PLA foamed at $130^{\circ} \mathrm{C}$ under different $\mathrm{CO}_{2}$ pressure.

$20 \mathrm{MPa}$ resulted more coalescence in LCB-PLA, which could also be due to the decreasing strength. However, a confusing phenomenon was that the cell size of linear PLA foamed under
$20 \mathrm{MPa} \mathrm{CO}_{2}$ decreased to nano-scale compared with the sample foamed under $16 \mathrm{MPa}$. It would be strange if only the strength of PLA was considered. As shown before, crystallization was also

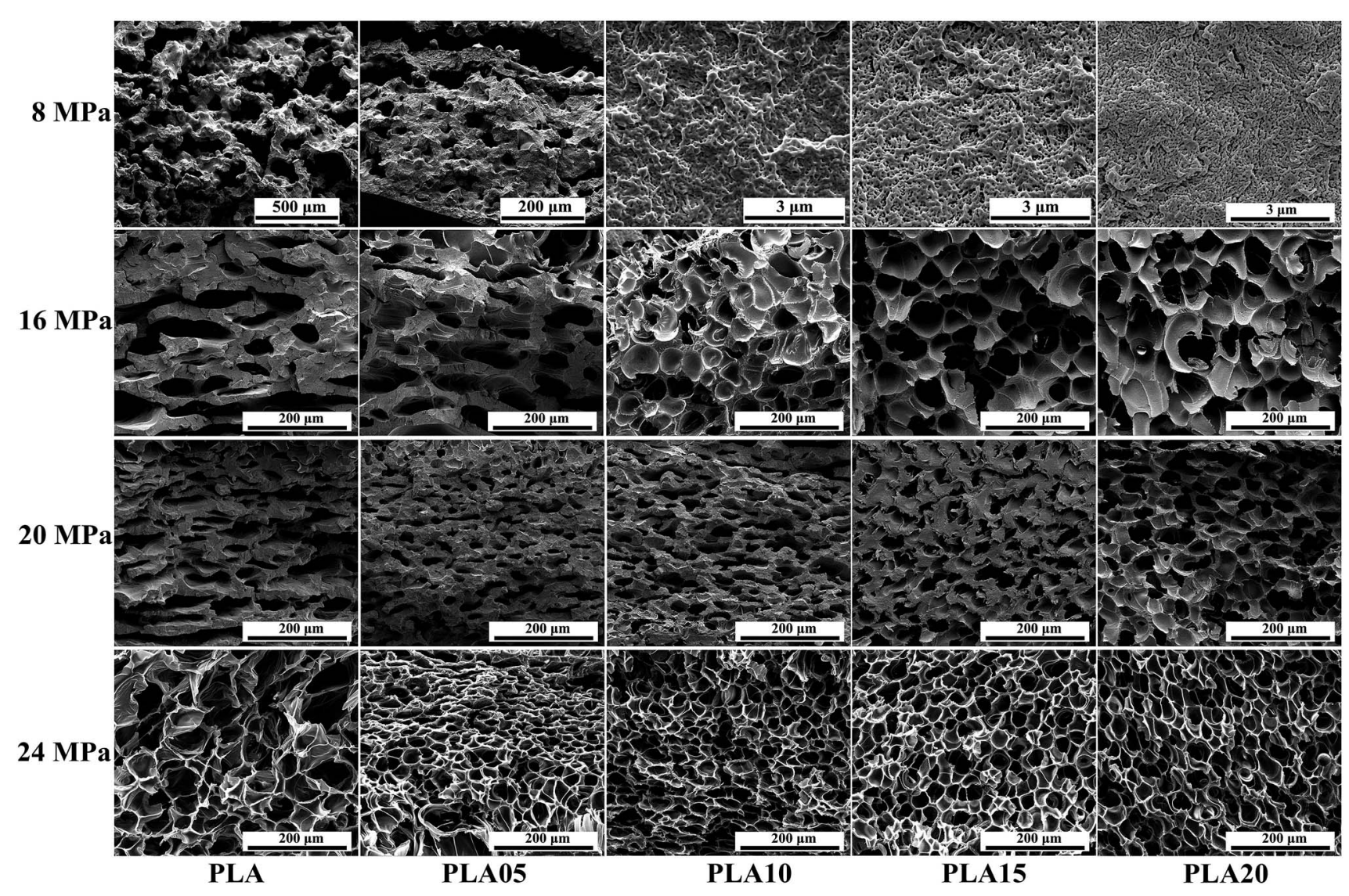

Fig. 10 SEM photos of linear PLA and LCB-PLA foamed at $150{ }^{\circ} \mathrm{C}$ under different $\mathrm{CO}_{2}$ pressure. 
a key reason to the foaming behavior of semi-crystallization polymer. As shown in others' report, ${ }^{40-42} \mathrm{CO}_{2}$ could induce the crystallization of polymer. In our study, the appearance of needle-like cells of samples foamed under higher pressure was the evidence of the existence of spherulites in the PLA. When foamed at $16 \mathrm{MPa}$, although more crystals were formed, it couldn't setoff the effect of strength decreasing. However, when foamed at $20 \mathrm{MPa}$, due to the $\mathrm{CO}_{2}$ induced crystallization, more crystals were formed and they were connected with each other, thus limited the growth of cells. For LCB-PLA, due to their higher matrix strength and higher crystal nucleation potential, the change of the cell size and cell density was not significant compare with linear PLA, it indicated that the processing window of PLA could be widen by the long-chain branching structure.

Cell morphology of samples foamed at $150{ }^{\circ} \mathrm{C}$ under different pressure was shown in Fig. 10, and the average cell diameter and cell density was shown in Fig. 11. The weaken matrix strength caused by the higher temperature resulted in micro-cells for most of samples under different conditions while the PLA10, PLA15 and PLA20 foamed under 8 MPa performed nano-cells. When foamed $16 \mathrm{MPa}$ and $20 \mathrm{MPa}$, the same phenomenon as the samples foamed at $150{ }^{\circ} \mathrm{C}$ under $12 \mathrm{MPa}$ was observed: with the increasing TMPTA content, the elliptic cells with horizontal semimajor axis changed to circular cells or oval with vertical semimajor axis, and the minimum cell diameter and maximum cell density was obtained in PLA05. Moreover, the cell wall became thinner and the coalescence was found. However, when foaming pressure was increased to $24 \mathrm{MPa}$, nearly all the samples possessed circular cells.

These results could also be explained by the change of matrix strength and the crystallization behavior of samples. For samples foamed under $8 \mathrm{MPa}$, due to the low $\mathrm{CO}_{2}$ content, the strength of the matrix of LCB-PLA with more than $1 \mathrm{wt} \%$ TMPTA was high enough to prevent the growth of the cells, thus the nano-cells appeared. With the increasing pressure, the enhanced plasticization effect due to the higher $\mathrm{CO}_{2}$ content impaired the matrix strength, which caused the micro-cells. The elliptic cells with horizontal semimajor axis of linear PLA and LCB-PLA with low TMPTA content was because of the collapse due to the weak matrix and it changed to circular cells or oval cells with vertical semimajor axis gradually with the increasing
TMPTA content which strengthen the matrix to withstand the pressure of cells. The elliptic cells with horizontal semimajor axis could only be observed in linear PLA and PLA05 when foamed under $12 \mathrm{MPa}$ and $16 \mathrm{MPa}$ while it even could be found in PLA20 when foamed under $20 \mathrm{MPa} \mathrm{CO}_{2}$. This was another evidence to prove the theory that matrix strength could cause these results because the increasing pressure could enhance the plasticization effect of $\mathrm{CO}_{2}$ which finally caused the weaker matrix when foamed under high pressure. When $\mathrm{CO}_{2}$ pressure reached $24 \mathrm{MPa}$, the cells became circular again. From our previous work, ${ }^{30}$ when $\mathrm{CO}_{2}$ pressure is higher than $20 \mathrm{MPa}$, the hydrostatic pressure of $\mathrm{CO}_{2}$ may offset its plasticization effect, and this may be the reason of the circular cells under high pressure. Still, the cells' coalescence was serious in liner PLA, while it was not observed in LCB-PLA, which suggested that the stronger matrix of LCB-PLA could prevent the coalescence of cells.

In addition, the crystallization behavior of PLA could also contribute to explain the cell morphology obtained. As mentioned before, $\mathrm{CO}_{2}$ could induce the crystallization of PLA. Thus, with the increasing $\mathrm{CO}_{2}$, more crystals nucleis formed in samples, and more spherulites were obtained. Analyzed from the data in Fig. 2, it was found the decreasing $\mathrm{CO}_{2}$ pressure resulted in increasing crystallinity. The less spherulite with increasing crystallinity in samples foamed under lower pressure would result in less crystal with larger diameter. The crystals in these samples were more perfect because too many crystals in the samples would impede the growth of each other. The more perfect crystals with larger cell size would connect with each other, thus limited the growth of cells, which finally resulted in nano-cells. However, when foamed under higher pressure, the imperfect crystals with low crystallinity had a little effect on restriction of the cell growth, which benefit to the formation of the micro-cells. Another difference of samples formed under low pressure and high pressure at $150{ }^{\circ} \mathrm{C}$ was that when foamed at low pressure ( $8 \mathrm{MPa})$, as shown in Fig. 13, the melting point of linear PLA was lower than $150{ }^{\circ} \mathrm{C}$ while that of LCB-PLA was higher than $150{ }^{\circ} \mathrm{C}$, which meant that the crystals found in linear PLA (which would be described later) could only be formed during foaming and that of LCB-PLA was formed during saturation. However, when foamed under high pressure $(\geq 12$ $\mathrm{MPa})$, the melting point of all samples was higher than $150^{\circ} \mathrm{C}$
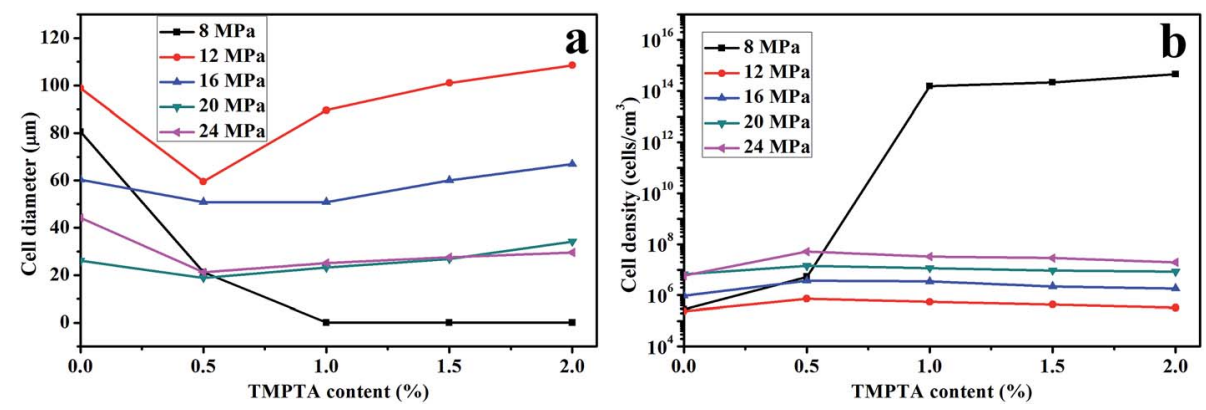

Fig. 11 (a) Average cell diameter and (b) cell density of linear PLA and LCB-PLA with different TMPTA content foamed at $150{ }^{\circ} \mathrm{C}$ under different $\mathrm{CO}_{2}$ pressure. 
from Fig. 3, thus the crystals of all samples was formed during foaming.

The magnification of the cell wall of PLA10 foamed under $16 \mathrm{MPa}$ was shown in Fig. 12. It was observed clearly in Fig. 12(b) that nano-cells were obtained on the cell wall of the sample, and some needle-like cells arranged like spherulites was also seen on the interface of the cell and the cell wall in Fig. 12(c). This phenomenon was also seen in other micro-cell samples. In our previous study, ${ }^{26}$ the needle-like cell was due to the constraint of the lamellae in the spherulite, which made the cell formed between lamellae was needle-like. It indicated that spherulites existed in the foamed sample. However, according to ref. 30, PLA was in melt state in this condition $\left(150{ }^{\circ} \mathrm{C}, 16 \mathrm{MPa}\right)$. Thus, the spherulite in the sample was not form during saturation, but formed during foaming. During foaming process, the $\mathrm{CO}_{2}$ was released from the samples, which enhanced the matrix strength, and some spherulites formed in the samples simultaneously. The enhanced matrix strength and the formation of spherulites restricted the growth of cells, this was reason that these needle-like cells
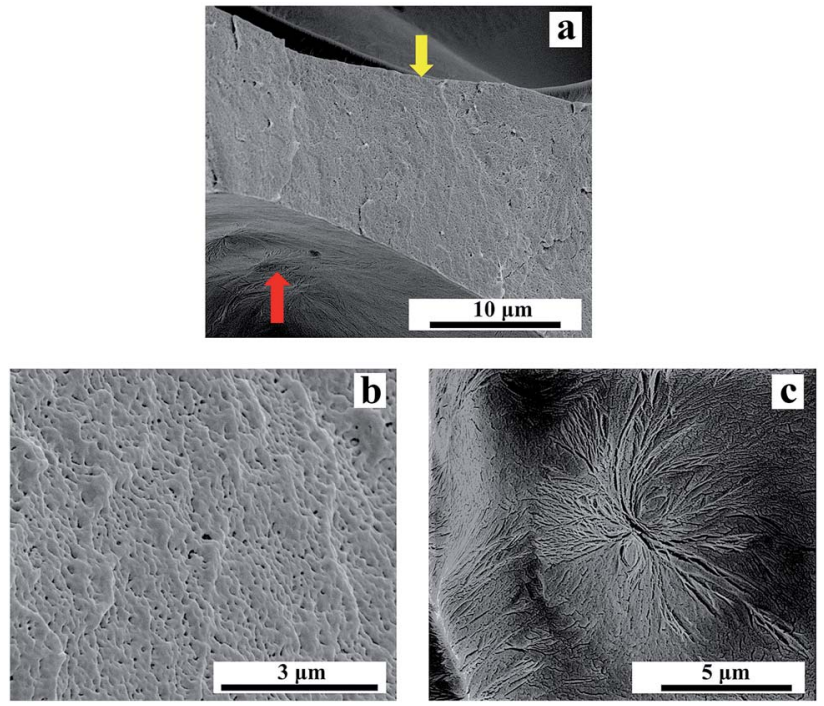

Fig. 12 (a) SEM photo PLA05 foamed at $150{ }^{\circ} \mathrm{C}$ under $16 \mathrm{MPa}$, (b) magnification of cell wall (pointed by yellow arrow in (a)) and (c) magnification of interface of cell and cell wall of (pointed by red arrow in (a)). arranged like spherulite was shown on the interface of the cell and the cell wall. During the growth of the micro-cell, the crystals were pushed to be percolated, so the cells formed following would be restricted by the connected crystals, which contributed to the formation of nano-cells on the cell wall. The nucleation potential of LCB-PLA made it more likely to form crystals than linear PLA, which finally increased the strength of the cell wall, thus circular cells or oval cells with vertical semimajor axis were formed.

\section{Expansion ratio of LCB-PLA}

Table 1 showed the cell diameter, cell density and expansion ratio of samples foamed at $150{ }^{\circ} \mathrm{C}$ under different $\mathrm{CO}_{2}$ pressure. It was found that when foamed under $8 \mathrm{MPa}$ and $12 \mathrm{MPa}$, the expansion ratio of linear PLA was bigger than that of PLA10, and when pressure was higher than $12 \mathrm{MPa}$, the PLA10 possessed higher expansion than linear PLA. From further analysis, it was obtained that although the linear PLA possessed higher cell diameter, the PLA10 possessed higher cell density, which meant both the cell diameter and cell density would decide the expansion ratio of samples. When foamed at low pressure, the larger cell diameter was the main reason of the bigger expansion ratio of PLA; when foamed at higher pressure, the cell diameter of both PLA and PLA10 was small, and the larger cell density would results in bigger expansion ratio. This result indicated that LCB-PLA could be used to prepared foams with big expansion ratio while its cell diameter is small.

Table 1 Cell diameter, cell density and expansion ratio of samples foamed at $150{ }^{\circ} \mathrm{C}$

\begin{tabular}{lclll}
\hline Samples & $\begin{array}{l}\text { Pressure } \\
(\mathrm{MPa})\end{array}$ & $\begin{array}{l}\text { Cell diameter } \\
(\mu \mathrm{m})\end{array}$ & $\begin{array}{l}\text { Cell density } \\
\left(\text { cells per } \mathrm{cm}^{3}\right)\end{array}$ & $\begin{array}{l}\text { Expansion } \\
\text { ratio }\end{array}$ \\
\hline PLA & 8 & 80.54 & $2.78 \times 10^{5}$ & 3.48 \\
& 12 & 98.85 & $2.40 \times 10^{5}$ & 4.12 \\
& 16 & 60.36 & $9.53 \times 10^{5}$ & 2.23 \\
& 20 & 26.08 & $6.68 \times 10^{6}$ & 1.80 \\
PLA10 & 8 & 0.05 & $1.53 \times 10^{14}$ & 1.02 \\
& 12 & 89.60 & $5.44 \times 10^{5}$ & 2.30 \\
& 16 & 50.85 & $3.44 \times 10^{6}$ & 3.09 \\
& 20 & 23.21 & $1.16 \times 10^{7}$ & 2.22
\end{tabular}
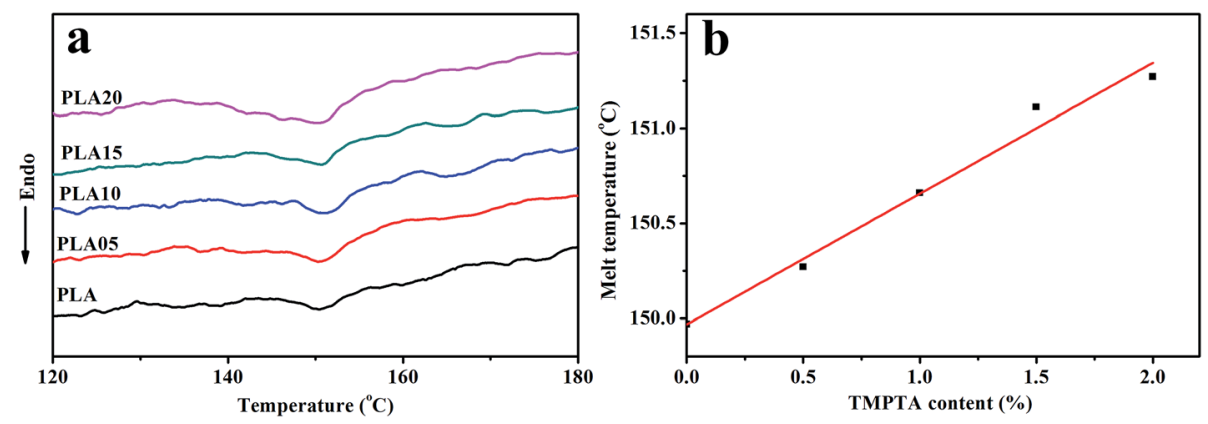

Fig. 13 (a) DSC curves of linear PLA and LCB-PLA under $8 \mathrm{MPa} \mathrm{CO}_{2}$ and (b) $T_{m}$ of linear PLA and LCB-PLA under $8 \mathrm{MPa} \mathrm{CO}$. 


\section{Conclusion}

The foaming behavior of LCB-PLA and its influence factors were studied in this manuscript. The high-pressure rheology and high-pressure DSC data showed that the viscosity, storage modulus and melting point of LCB-PLA increased with the increasing TMPTA content under $\mathrm{ScCO}_{2}$, and the long-chain branching structure was also benefit to the crystal nucleation of PLA. Furthermore, the different cell morphology of LCB-PLA foams with different saturation time indicated that the rheology properties and crystallization behaviors of LCB-PLA affected the cell morphology especially at high temperature and pressure. The cell morphology of samples foamed at $130{ }^{\circ} \mathrm{C}$ and $140{ }^{\circ} \mathrm{C}$ under $12 \mathrm{MPa} \mathrm{CO}_{2}$ were nearly same, while the remarkable result was observed when foaming temperature increased to $142{ }^{\circ} \mathrm{C}$ at which nano-cells were formed in PLA and PLA05 and micro-cells existed in other samples. With increasing temperature, the elliptic cells with horizontal semimajor axis were found in linear PLA and PLA05 while the circular cells or oval cells with vertical semimajor axis existed in PLA10, PLA15 and PLA20. The LCB-PLA also shown better cell morphology (less coalescence, none collapse and uniform cell distribution) than linear PLA under higher pressure. The stronger matrix strength and higher nucleation potential of LCB-PLA should be the main reason of its better foaming behavior. All the results indicated that the introduction of long-chain branching structure could widen the foaming processing window of PLA and adjust the expansion ratio of foams. The UV-induced reactive extrusion provides us with a new method to prepare high melt strength and pollution-free PLA, which could benefit its high temperature and high pressure foaming.

\section{Acknowledgements}

This work is supported by National Natural Science Foundation of China (No. 51373103 and 51421061) Science and Technology Department of Sichuan Province (No. $2015 \mathrm{HH} 0026$ and 2013GZ0152), opening project of the Key Laboratory of Polymer Processing Engineering, Ministry of Education, China.

\section{References}

1 T. He, X. Liao, Y. He and G. Li, Novel Electric Conductive Polylactide/carbon Nanotubes Foams Prepared by Supercritical $\mathrm{CO}_{2}$, Prog. Nat. Sci.: Mater. Int., 2013, 23, 395401.

2 Y. Liu, L. Wang, Y. He, Z. Fan and S. Li, Non-isothermal Crystallization Kinetics of Poly(L-lactide), Polym. Int., 2010, 59(12), 1616-1621.

3 H.-Y. Mi, M. R. Salick, X. Jing, B. R. Jacques, W. C. Crone, X.-F. Peng and L.-S. Turng, Characterization of Thermoplastic Polyurethane/polylactic acid (TPU/PLA) Tissue Engineering Scaffolds Fabricated by Microcellular Injection Molding, Mater. Sci. Eng., C, 2013, 33(8), 47674776.

4 K. Li, J. Peng, L.-S. Turng and H.-X. Huang, Dynamic Rheological Behavior and Morphology of Polylactide/ poly(butylenes adipate-co-terephthalate) Blends with Various Composition Ratios, Adv. Polym. Technol., 2011, 30(2), 150-157.

5 S. Pilla, A. Kramschuster, J. Lee, C. Clemons, S. Gong and L.-S. Turng, Microcellular Processing of Polylactidehyperbranched Polyester-nanoclay Composites, J. Mater. Sci., 2010, 45(10), 2732-2746.

6 J. Liu, S. Zhang, L. Zhang and Y. Bai, Crystallization Behavior of Long-Chain Branching Polylactide, Ind. Eng. Chem. Res., 2012, 51(42), 13670-13679.

7 N. Najafi, M.-C. Heuzey, P. J. Carreau, D. Therriault and C. B. Park, Mechanical and Morphological Properties of Injection Molded Linear and Branched-polylactide (PLA) Nanocomposite Foams, Eur. Polym. J., 2015, 73, 455-465.

8 M. Nofar, A. Ameli and C. B. Park, The Thermal Behavior of Polylactide with Different D-Lactide Content in the Presence of Dissolved $\mathrm{CO}_{2}$, Macromol. Mater. Eng., 2014, 299(10), 1232-1239.

9 H. Fang, Y. Zhang, J. Bai, Z. Wang and Z. Wang, Bimodal Architecture and Rheological and Foaming Properties for Gamma-irradiated Long-chain Branched Polylactides, RSC Adv., 2013, 3(23), 8783.

$10 \mathrm{X}$. Liao, H. Zhang and T. He, Preparation of Porous Biodegradable Polymer and Its Nanocomposites by Supercritical $\mathrm{CO}_{2}$ Foaming for Tissue Engineering, $J$. Nanomater., 2012, 2012, 1-12.

11 L. Sansone, A. Aldi, P. Musto, E. Di Maio, E. Amendola and G. Mensitieri, Assessing the Suitability of Polylactic Acid Flexible Films for High Pressure Pasteurization and Sterilization of Packaged Foodstuff, J. Food Eng., 2012, 111(1), 34-45.

12 W. Liu, X. Wang, H. Li, Z. Du and C. Zhang, Study on rheological and extrusion foaming behaviors of chainextended poly(lactic acid)/clay nanocomposites, J. Cell. Plast., 2013, 49, 535-554.

13 M. Nofar and C. B. Park, Poly(lactic acid) foaming, Prog. Polym. Sci., 2014, 39(10), 1721-1741.

14 S. C. Frerich, Biopolymer foaming with supercritical $\mathrm{CO}_{2}-$ Thermodynamics, foaming behaviour and mechanical characteristics, J. Supercrit. Fluids, 2015, 96, 349-358.

15 J.-P. Garancher and A. Fernyhough, Expansion and dimensional stability of semi-crystalline polylactic acid foams, Polym. Degrad. Stab., 2014, 100, $21 \mathrm{e} 28$.

16 Q. Ren, J. Wang, W. Zhai and S. Su, Solid State Foaming of Poly(lactic acid) Blown with Compressed $\mathrm{CO}_{2}$ : Influences of Long Chain Branching and Induced Crystallization on Foam Expansion and Cell Morphology, Ind. Eng. Chem. Res., 2013, 52, 13411-13421.

17 R. Liao, W. Yu and C. Zhou, Rheological Control in Foaming Polymeric Materials: II. Semi-crystalline Polymers, Polymer, 2010, 51(26), 6334-6345.

18 K. Mohebbi and N. G. Ebrahimi, Preparation and Rheology Characterization of Branched Polypropylene During Reactive Extrusion Process, Iran. Polym. J., 2015, 24(4), 309-316.

19 K. Chikhalikar, S. Banik, L. B. Azad, K. Jadhav, S. Mahajan, Z. Ahmad, S. Kulkarni, S. Gupta, P. Doshi, H. Pol and 
A. Lele, Extrusion Film Casting of Long Chain Branched Polypropylene, Polym. Eng. Sci., 2015, 55(9), 1977-1987.

20 A. Mohebbi, F. Mighri, A. Ajji and D. Rodrigue, Current Issues and Challenges in Polypropylene Foaming: A Review, Cell. Polym., 2015, 34(6), 299-337.

21 C. B. Park and L. K. Cheung, A Study of Cell Nucleation in the Extrusion of Polypropylene Foams, Polym. Eng. Sci., 1997, 37, 1-10.

22 K. Wang, S. Wang, F. Wu, Y. Pang, W. Liu, W. Zhai and W. Zheng, A New Strategy for Preparation of Long-chain Branched Polypropylene via Reactive Extrusion with Supercritical $\mathrm{CO}_{2}$ Designed for an Improved Foaming Approach, J. Mater. Sci., 2015, 51(5), 2705-2715.

23 C.-Q. Chen, D.-M. Ke, T.-T. Zheng, G.-J. He, X.-W. Cao and X. Liao, An Ultraviolet-Induced Reactive Extrusion To Control Chain Scission and Long-Chain Branching Reactions of Polylactide, Ind. Eng. Chem. Res., 2016, 55(3), 597-605.

24 X. Liao, H. Xu, S. Li, C. Zhou, G. Li and C. B. Park, The Effects of Viscoelastic Properties on the Cellular Morphology of Silicone Rubber Foams Generated by Supercritical Carbon Dioxide, RSC Adv., 2015, 5(129), 106981-106988.

25 M. Nofar, W. Zhu, C. B. Park and J. Randall, Crystallization Kinetics of Linear and Long-Chain-Branched Polylactide, Ind. Eng. Chem. Res., 2011, 50(24), 13789-13798.

26 J. Li, G. He, X. Liao, H. Xu, Q. Yang and G. Li, Nanocellular and Needle-like Structures in Poly(L-lactic acid) Using Spherulite Templates and Supercritical Carbon Dioxide, RSC Adv., 2015, 5, 36320-36324.

27 M. Nofar, Y. Guo and C. B. Park, Double Crystal Melting Peak Generation for Expanded Polypropylene Bead Foam Manufacturing, Ind. Eng. Chem. Res., 2013, 52(6), 2297-2303.

28 M. Nofar, A. Ameli and C. B. Park, Development of Polylactide Bead Foams with Double Crystal Melting Peaks, Polymer, 2015, 69, 83-94.

29 W. Zhai, Y.-W. Kim and C. B. Park, Steam-Chest Molding of Expanded Polypropylene Foams. 1. DSC Simulation of Bead Foam Processing, Ind. Eng. Chem. Res., 2010, 49, 9822-9829.

30 E. Huang, X. Liao, C. Zhao, C. B. Park, Q. Yang and G. Li, Effect of Unexpected $\mathrm{CO}_{2}$ 's Phase Transition on the HighPressure Differential Scanning Calorimetry Performance of Various Polymers, ACS Sustainable Chem. Eng., 2016, 4, 1810-1818.
$31 \mathrm{X}$. Liao and A. V. Nawaby, The sorption behaviors in PLLA$\mathrm{CO}_{2}$ system and its effect on foam morphology, J. Polym. Res., 2012, 19(3), 1-9.

32 O. S. Knauer, M. G. Pastore Carbone, A. Braeuer, E. Di Maio and A. Leipertz, Investigation of $\mathrm{CO}_{2}$ Sorption in Molten Polymers at high Pressures Using Raman line Imaging, Polymer, 2013, 54(2), 812-818.

33 X. Liao, A. V. Nawaby, P. Whitfield, M. Day, M. Champagne and J. Denault, Layered Open Pore Poly(L-lactic acid) Nanomorphology, Biomacromolecules, 2006, 7, 2937-2941.

34 X. Liao, A. V. Nawaby and P. S. Whitfield, Carbon dioxideinduced crystallization in poly(L-lactic acid) and its effect on foam morphologies, Polym. Int., 2010, 59(12), 1709-1718.

35 X. Liao, A. V. Nawaby and H. E. Naguib, Porous poly(lactic acid) and PLA-nanocomposite structures, J. Appl. Polym. Sci., 2012, 124(1), 585-594.

36 X.-L. Jiang, T. Liu, Z.-M. Xu, L. Zhao, G.-H. Hu and W.-K. Yuan, Effects of Crystal Structure on the Foaming of Isotactic Polypropylene Using Supercritical Carbon Dioxide as a Foaming Agent, J. Supercrit. Fluids, 2009, 48(2), 167-175.

37 S. Pilla, S. G. Kim, G. K. Auer, S. Gong and C. B. Park, Microcellular Extrusion-foaming of Polylactide with Chainextender, Polym. Eng. Sci., 2009, 49(8), 1653-1660.

38 M. Mihai, M. A. Huneault and B. D. Favis, Rheology and Extrusion Foaming of Chain-branched Poly(lactic acid), Polym. Eng. Sci., 2010, 50(3), 629-642.

39 N. Najafi, M.-C. Heuzey, P. J. Carreau, D. Therriault and C. B. Park, Rheological and Foaming Behavior of Linear and Branched Polylactides, Rheol. Acta, 2014, 53(10-11), 779-790.

40 K. Mizoguchi, T. Hirose, Y. Naito and Y. Kamiya, $\mathrm{CO}_{2}$ induced Crystallization of Poly(ethylene-terephthalate), Polymer, 1987, 28(8), 1298-1302.

41 A. Erriguible, T. Fadli and P. Subra-Paternault, A Complete 3D Simulation of a Crystallization Process Induced by Supercritical $\mathrm{CO}_{2}$ to Predict Particle Size, Comput. Chem. Eng., 2013, 52, 1-9.

42 T. Liu, L. Zhao and X. Zhu, $\mathrm{CO}_{2}$-induced Crystallization of Isotactic Polypropylene by Annealing Near Its Melting Temperature, J. Macromol. Sci., Part B: Phys., 2010, 49(4), 821-832. 